\title{
Haji Dua Kali: Kajian terhadap Motif Pengulangan Haji Masyarakat Muslim di Kudus
}

\author{
Salmah Faatin ${ }^{{ }^{*}}$ \\ ${ }^{1}$ Institut Agama Islam Negeri Kudus, Kudus, Indonesia \\ *salma@iainkudus.ac.id
}

\begin{abstract}
Abstrak
Fenomena pengulangan haji di masyarakat Indonesia layak mendapatkan perhatian karena frekuensi keberangkatan haji telah menjadi trend dan gaya hidup. Motif dan spiritualitas ibadah haji telah keluar dari substansi syariatnya. Artikel ini bertujuan mengungkap fenomena pengulangan haji masyarakat muslim Kudus beserta motifnya. Pendekatan fenomenologi digunakan untuk mengidentifikasi dan menggambarkan fenomena pengulangan haji. Motif mengulang haji di kalangan masyarakat muslim Kudus dikaji dan dianalisis menggunakan pendekatan psikologi dan sosiologi. Dalam artikel ini dibahas tentang pengalaman hidup informan yang dimaknai secara subjektif serta mencari inti dari makna pengalaman individu terkait ibadah haji. Hasilnya dapat diungkapkan bahwa pengulangan haji di kalangan masyarakat Muslim Kudus disebabkan faktor politik, ekonomi dan sosial keagamaan. Dari kajian ini diharapkan dapat menjadi bahan evaluasi untuk reinterpretasi dan rekonstruksi pemaknaan masyarakat terhadap ibadah haji yang humanis sebagaimana ideal moral pensyariatannya.
\end{abstract}

Kata kunci: Motif ibadah haji, masyarakat Kudus, pengulangan haji 


\begin{abstract}
The phenomenon of Hajj repetition in Indonesian deserves big attention because the frequency of Hajj has become a trend and lifestyle. The motives and spirituality of the Hajj have come out of the substance of the Sharia. This article aims to reveal the phenomenon and its motives for the hajj repetition of the Muslim community Kudus Central Java. The phenomenological approach is used to identify and describe the phenomenon of Hajj repetition. The motive of repeating the Hajj among the Kudus Muslim community was studied and analyzed using a psychological and sociological approach. In this article, we discuss the life experiences of informants who are interpreted subjectively and look for the essence of the meaning and individual experiences related to the Hajj. The result can be revealed that the repetition of the Hajj among the Muslim community is due to political, economic and socio-religious factors. From this study, it is expected to be an evaluation material for the reinterpretation and reconstruction of the meaning of the community towards the humanist pilgrimage.
\end{abstract}

Keywords: Kudus people, motive for the pilgrimage, the repetition of the hajj

\title{
Pendahuluan
}

Ibadah haji merupakan salah satu pilar (rukun) Islam yang disyariatkan pada tahun ke enam hijriyah. Teks-teks tentang anjuran untuk melaksanakannya tertuang dalam ayat-ayat al Quran maupun hadis. Dalam ayat-ayat tentang haji dijelaskan anjuran melaksanakannya bagi orang yang mampu serta perintah untuk menyempurnakan ibadah ini. Pahala melaksanakan ibadah haji mabrur dinyatakan dalam hadis Nabi, berupa jaminan masuk surga. Atas jaminan inilah kaum muslim dari berbagai kalangan berlomba-lomba untuk memenuhi perintah berhaji dengan berbagai cara (Ichwan, 2008, hal. 126). Bahkan orang yang sudah pernah melaksanakan ibadah haji sekali berkeinginan untuk mengulanginya di tahun berikutnya tanpa menimbang dampak kebermaknaannya dalam ranah sosial masyarakat (Sujadi, 2017), kendati ayatayat al Quran tidak secara eksplisit menyatakan berapa kali sebaiknya frekuensi melaksanakan ibadah haji (Lestari, 2014). Justru dalam hadis Nabi tersirat dengan jelas dan tegas bahwa kewajiban ibadah haji hanya dilakukan sekali seumur hidup (Fatkhi, 2018).

Fenomena menarik dari pengalaman ibadah haji adalah pengulangan haji di kalangan sebagian masyarakat muslim Indonesia, yakni mengulangi ibadah haji yang kedua dan seterusnya. Artikel ini dilakukan untuk mengungkap motif mengulang haji 
dan selanjutnya dianalisis menggunakan perspektif psikologi. Kajian terhadap motif pengulangan haji semakin diperlukan untuk dapat mengevaluasi, menempatkan, dan mengarahkan motif individu kepada tujuan hakiki disyariatkannya ibadah haji. Karena pensyariatan ibadah haji sarat dengan pendidikan emosional-spiritual untuk bekal mewujudkan perilaku kepedulian dan penebaran kedamaian dalam kehidupan.

Kajian spesifik tentang motif pengulangan haji di Indonesia belum dilakukan, kendati artikel yang terkait haji dan problematikanya sudah dilakukan dalam berbagai sudut pandang. Lenni Lestari (Lestari, 2014) mengkaji tafsir ayat-ayat tentang haji dan substansinya dalam konteks pelaksanaan haji di Indonesia dengan menggunakan pendekatan normatif-historis dan sosiologis. Agus Sujadi (Sujadi, 2017) mengkaji pengulangan haji dari prespektif hukum Islam. Pengulangan haji disinyalir sebagai penyebab terjadinya waiting list atau antrian haji yang sangat panjang. Sementara mengulang haji yang kedua dan seterusnya hukumnya sunah. Dalam prespektif kaidah fikih, perbuatan wajib tidak dapat digantikan atau digeser dengan perbuatan sunah. Sudut pandang jarimah ta'zir yang menekankan kemaslahatan umum, pengulangan haji dikategorikan perbuatan kriminal yang harus dikenai sanksi. Pengulang haji kedua dikenai sanksi pelipatgandaan biaya haji, haji ketiga dikenai sanksi dicoret dari daftar antrian haji, haji yang keempat dan seterusnya tidak dapat mendaftar haji. Nida Farhan (2017) meneliti tentang problematika waiting list dalam penyelenggaraan haji di Indonesia menggunakan multi-prespektif. Kritik terhadap minimnya kesadaran humanisme setelah berhaji juga diungkap oleh Nisa (2017) dengan menggunakan kajian hadis tematik. Kajian tentang pengalaman-pengalaman beragama pada orang yang sedang berhaji dilakukan oleh Perdana (2017). Penelitian tersebut bertujuan untuk mengidentifikasi tema-tema pengalaman beragama yang dialami oleh orang-orang yeng berhaji yang selanjutnya diklasifikasi menjadi empat tipe berdasarkan teori Stark. Penelitian terakhir tentang pengulangan haji ditinjau dari prespektif ma'anil hadis telah dilakukan Fatkhi (Fatkhi, 2018).

\section{Kajian Teori}

Pelaksanaan ibadah haji sampai saat ini masih menyisakan beragam problem yang menuntut perhatian dan pemikiran untuk ditemukan solusi alternatif (Rapiko, 
2011). Ibadah haji yang sejatinya menjadi media pendidikan emosional spiritual seakan sarat formalitas namun gersang makna (Istianah, 2017, hal. 43). Pengalamanpengalaman beragama saat berhaji seakan-akan hanya euforia yang bersifat musiman dan eksidental. Ditambah lagi dengan munculnya pemahaman masyarakat bahwa tingginya kadar kesalehan dan ketakwaan seseorang bisa diukur dan diwujudkan dengan menambah frekuensi pelaksanaan haji dan umrah (Istianah, 2017). Dalam prespektif sosiologis, fenomena tersebut merupakan salah satu gejala dari struktur sosial masyarakat (Istianah, 2017). Haji diposisikan oleh sebagian masyarakat sebagai simbol yang sarat nilai kebanggaan, sehingga harus berjuang keras dan bersaing meraihnya. Bahkan tatkala simbol-simbol status (status symbols) telah tercapai, masyarakat berpikir untuk terus meningkatkankannya agar mendapat pengakuan dan penghargaan (Zainuddin, 2013).

Prespektif psikologi, semua perilaku manusia, termasuk mengulang ibadah haji, hakikatnya mempunyai motif (Alex Shobur, 2003), sehingga dorongan kuat dalam masyarakat untuk mengulang haji perlu diungkap, dikaji dan dianalisis. Perilaku mengulang haji, secara individual timbul karena adanya dorongan dari dalam sebagai faktor intern. Perilaku keagamaan dipengaruhi juga oleh pengalaman keagamaan, struktur kepribadan serta unsur kejiwaan lainnya (Jalaluddin, 2015, hal. 90). Untuk memahami perilaku manusia secara sempurna, yang perlu dimengerti dan dipahami terlebih dahulu adalah apa dan bagaimana motifnya, karena memberikan tujuan dan arah pada perilaku (Alex Shobur, 2003). Dalam hal ini motif disebut sebagai penyebab psikologis yang menjadi sumber dan tujuan dari tindakan dan perbuatan mengulang haji hingga dua kali dan seterusnya.

Perilaku mengulang haji dapat dikatakan sebagai tingkah laku bermotivasi yang dilatarbelakangi oleh adanya kebutuhan dan diarahkan pada pencapaian suatu tujuan (lingkaran motivasi atau motivational cycle), agar suatu kebutuhan terpenuhi dan suatu kehendak terpuaskan. Karena motif bukanlah sekedar dorongan fisik, tetapi juga orientasi kognitif elementer yang diarahkan pada pemuasan kebutuhan (Priyadi, 2017, hal. 50). Zakiah Darajat (1970, hal. 25) membagi kebutuhan manusia menjadi kebutuhan primer (kebutuhan jasmaniah) dan kebutuhan sekunder (kebutuhan rohaniah). Kebutuhan sekunder dibagi menjadi enam jenis, pertama, kebutuhan akan 
rasa kasih sayang, kedua, kebutuhan akan rasa aman, ketiga, kebutuhan akan rasa harga diri, keempat, kebutuhan akan rasa bebas, kelima, kebutuhan akan rasa sukses, keenam, kebutuhan akan rasa ingin tahu.

Salah satu teori motivasi yang paling terkenal adalah teori hierarki kebutuhan Maslow, bahwa kebutuhan manusia sebagai pendorong (motivator) membentuk suatu hierarki atau jenjang peringkat. Maslow menggolongkan kebutuhan manusia pada lima tingkat kebutuhan (five hierarchy of needs). Pertama, kebutuhan-kebutuhan yang bersifat fisiologis (physiological needs), yakni kebutuhan paling dasar berupa kebutuhan manusia untuk mempertahankan hidupnya secara fisik, yakni kebutuhan makanan, minuman, tempat berteduh, seks, tidur, dan oksigen. Di antara sekian banyak kebutuhan fisik, makanan adalah yang utama, menyusul pakaian, perumahan, dan seterusnya.

Kedua, kebutuhan akan rasa aman (safety needs). Sejatinya kebutuhan rasa aman mengarah pada dua bentuk, kebutuhan keamanan jiwa dan kebutuhan keamanan harta. Kebutuhan ini meliputi kebutuhan perlindungan, keamanan hukum, kebebasan dari rasa takut dan kecemasan. Ketiga, kebutuhan cinta dan memiliki-dimiliki (belongingness and love needs). Kebutuhan ini muncul ketika kebutuhan sebelumnya telah dipenuhi secara rutin. Maslow mengatakan bahwa semua orang membutuhkan rasa diingini dan diterima orang lain. Ada yang memuaskan kebutuhan ini dengan berteman, berkeluarga, dan berorganisasi. Tanpa ikatan ini orang akan merasa kesepian, kendati hal ini tidak tidak selalu memberikan dampak negatif pada kepribadian. Cinta tidak boleh dikacaukan dengan seks, yang dapat dipandang sebagai kebutuhan fisiologis semata-mata. Cinta, sebagaimana rumusan Carl Rogers adalah keadaan dimengerti secara mendalam dan diterima dengan sepenuh hati.

Keempat, kebutuhan penghargaan (esteem needs). Kebutuhan ini menjurus pada kepercayaan terhadap diri sendiri dan perasaan diri berharga. Maslow membagi kebutuhan penghargaan dalam dua jenis, yakni penghargaan yang didasarkan pada respek terhadap kemampuan, kemandirian, dan perwujudan kita sendiri serta penghargaan yang didasarkan atas penilaian orang lain. Penghargaan yang kedua tersebut dapat dilihat dengan baik dalam usaha untuk mengapresiasikan diri dan 
mempertahankan status. Kelima, kebutuhan aktualisasi diri (self-actualization needs). Kebutuhan ini muncul jika kebutuhan lainnya telah terpenuhi, karena kebutuhan aktualisasi diri menjadi semakin penting. Maslow menggambarkan kebutuhan aktualisasi diri sebagai hasrat untuk menjadi diri sepenuh kemampuannya sendiri, menjadi apa saja menurut kemampuannya. Maslow mendasarkan teori aktualisasi diri ini dengan asumsi bahwa setiap manusia memiliki hakikat instrinsik yang baik, dan hal itu memungkinkan untuk mewujudkan perkembangan. Perkembangan yang sehat apabila manusia mengaktualisasikan diri dan mewujudkan segenap potensinya (Andjarwati, 2015).

Kebutuhan aktualisasi diri, menurut Maslow, hanya mampu dicapai oleh sedikit orang, karena gerakan ke arah aktualisasi diri ini tidak secara otomatis dan tidak mudah. Hal ini dikarenakan aktualisasi diri adalah kebutuhan naluriah yang paling lemah, bahkan jauh lebih lemah dari kebutuhan dasar, sehingga dapat dengan mudah dikuasai oleh kebiasaan, tekanan, kebudayaan dan sikap yang salah terhadap aktualisasi diri. Selain itu, orang-orang sering takut untuk mengetahui diri sendiri yang sebenarnya penting untuk aktualisasi diri yang pada umumnya memerlukan lingkungan kepada seseorang untuk bebas mengungkapkan dirinya, menjelajah memilih pelakunya, dan mengajar nilai-nilai kebenaran, keadilan dan kejujuran. Pada dasarnya setiap orang memiliki aktualisasi yang berbeda. Selain itu aktualisasi diri tidak melibatkan bakat istimewa atau kegiatan yang artistik dan kreatif dan dapat diwujudkan dalam berbagai aktifitas manapun. Orang yang mengaktualisasi diri dimotivasi oleh meta-kebutuhan (growth motivation/being motives/metamotives) yang berorientasi pada penyesuaian kehidupan individu dengan kecenderungan-kecenderungan aktualisasi diri yang unik dan ditujukan untuk meningkatkan pengalaman atau ketegangan yang mengarah pada pertumbuhan dalam diri (Priyadi, 2017).

Teori motivasi lain yakni teori McCelland tentang kebutuhan untuk berprestasi (needs for achievement) (Alex Shobur, 2003). Konsep ini dikenal dengan simbol yang kemudian menjadi sangat terkenal, yaitu n-Ach. Dalam batas tertentu kebutuhan berprestasi adalah sesuatu yang ada dan dibawa sejak lahir. Namun di sisi lain kebutuhan berprestasi dalam banyak hal adalah sesuatu yang ditumbuhkan, dikembangkan, hasil dari mempelajari melalui interaksi dengan lingkungan. Kebutuhan 
berprestasi, menurut McCelland, adalah suatu daya dalam mental manusia untuk melakukan suatu kegiatan yang lebih baik, lebih cepat, lebih efektif dan lebih efisien daripada kegiatan yang dilakukan sebelumnya. Hal ini disebabkan oleh daya pendorong yang dinamakan virus mental. Jika berjangkit dalam jiwa manusia, maka daya tersebut akan berkembang baik dengan cepat, dan daya tersebut akan meluas menimbulkan dampak dalam kehidupan.

Teori motivasi lain dikembangkan oleh Vroom, yakni teori harapan (expectancy theory) (Alex Shobur, 2003). Teori ini memiliki tiga asumsi pokok. Pertama, setiap individu percaya bahwa ia berperilaku dengan cara tertentu, ia akan memperoleh hal tertentu. Hal ini disebut harapan hasil (outcome expectancy). Jadi, harapan hasil adalah penilaian subyektif seseorang atas kemungkinan bahwa suatu hasil tertentu akan muncul dari tindakan orang tersebut. Kedua, setiap hasil mempunyai nilai atau daya tarik bagi orang-orang tertentu. Hal disebut valensi (valency), nilai yang diberikan orang pada suatu hasil yang diharapkan. Ketiga, setiap hasil berkaitan dengan suatu persepsi mengenai seberapa sulit mencapai hasil tersebut. Hal ini disebut harapan usaha (effort expectancy), yakni kemungkinan bahwa usaha seseorang akan menghasilkan pencapaian tujuan tertentu. Orang akan termotivasi apabila ia percaya bahwa perilaku tertentu akan mampu mencapai tujuannya. Hasil tersebut mempunyai nilai positif, dan dapat dicapai dengan usaha yang dilakukan seseorang. Jadi, seseorang akan memilih ketika melihat beberapa alternatif, tingkat kinerja yang memiliki kekuatan motivasional tertinggi yang berkaitan dengannya (Alex Shobur, 2003).

Psikologi memandang tingkah laku manusia (human behavior) sebagai reaksi yang dapat bersifat sederhana ataupun bersifat kompleks. Teori perilaku (behavioral theory) memiliki asumsi dasar bahwa perubahan dalam cara orang menilai perilaku akan dihasilkan lebih efisien dengan menitikberatkan perilaku yang dapat diobservasi daripada kepercayaan dan cara berpikir, seperti yang disarankan teori rasional. Faktanya, sikap dan pikiran internal dapat dipahami dengan mengobservasi dan mengukur perilaku nyata. Meski hal demikian tidak berarti bahwa perilaku tidak dipengaruhi oleh proses internal dan berpikir. Hal ini menunjukkan bahwa perilakuperilaku yang dapat diobservasi adalah fokus perhatian (Alex Shobur, 2003). 
Para pakar psikologi mengklasifikasikan motif ke dalam beberapa golongan dan dengan beragam cara. Klasifikasi motif yang banyak dikenal di kalangan orang yang menekuni psikologi yaitu: pertama, motif primer dan motif sekunder; kedua, motif instrinsik dan motif ekstrinsik; ketiga, motif tunggal dan motif bergabung (kompleks); keempat, motif mendekat dan motif menjauh; kelima, motif sadar dan tidak sadar dan; keenam, motif biologis, sosiogenetis, dan teogenetis (Alex Shobur, 2003). Disebut motif primer jika dilatarbelakangi oleh proses fisio-kemis di dalam tubuh seperti motif lapar, haus, seks, bernapas, dan istirahat yang semuanya bertujuan menjaga keseimbangan tubuh (homeostatis). Adapun motif sekunder adalah yang tidak langsung terkait dengan organisme individu. Motif instrinsik yakni motif-motif yang dapat berfungsi tanpa harus dirangsang dari luar, sementara motif ekstrinsik harus ada pendorong dari luar. Motif mendekat dan menjauh yakni jika stimulus yang menimbulkan respon mendekat (positif) atau menjauh (negatif). Kedua motif ini dapat digabung dengan motif primer dan sekunder sehingga menjadi empat jenis motif baru, yaitu motif primer mendekat, motif primer menjauh, motif sekunder mendekat, dan motif sekunder menjauh.

Tulisan ini akan mengkaji perilaku dan motif masyarakat muslim Kudus dalam mengulang haji berdasarkan teori harapan (expectancy theory) yang dikembangkan oleh Vroom. Hal ini didasarkan pada asumsi bahwa setiap individu percaya pengulangan haji adalah bagian dari fadhal yang dianugerahkan Allah untuk kesempurnaan iman. Hal ini disebut harapan hasil (outcome expectancy), yakni penilaian subyektif masyarakat atas kemungkinan bahwa semakin sering diulang, maka ibadah haji semakin sempurna. Kedua, dampak mengulang ibadah haji dalam beberapa aspek menjadi daya tarik tersendiri bagi masyarakat Kudus. Hal disebut valensi (valency), nilai yang diberikan orang pada suatu hasil yang diharapkan. Ketiga, masyarakat Kudus menyadari bahwa melaksanakan ibadah haji memerlukan biaya besar, tenaga, dan upaya yang kuat. Namun, hasil dan dampak berhaji disadari masyarakat Kudus setara dengan besarnya biaya dan upaya yang telah dikeluarkan. Haji yang diulang diyakini akan menambah kualitas dan kuantitas hasil yang didapat setelah berhaji. Hal ini disebut harapan usaha (effort expectancy), yakni kemungkinan bahwa usaha seseorang akan mencapai tujuan tertentu. 
Selanjutnya motif-motif masyarakat Kudus mengulang haji diklasifikasikan berdasarkan beberapa golongan. Pertama, motif primer dan motif sekunder; kedua, motif instrinsik dan motif ekstrinsik; ketiga, motif tunggal dan motif bergabung (kompleks); keempat, motif mendekat dan motif menjauh; kelima, motif sadar dan tidak sadar; dan keenam, motif biologis, sosiogenetis dan teogenetis. Analisis dan kajian motif mengulang haji dalam penelitian ini bukan untuk menjustifikasinya secara normatifdogmatis yang berakhir pada penentuan sah dan tidaknya perilaku mengulang haji, tetapi lebih untuk mengungkap serta mengkajinya dengan pendekatan psikologi, baik psikologi umum maupun psikologi agama.

\section{Metode}

Artikel ini menggunakan metode yang bersifat deskriptif-analitis tentang fenomena pelaksanaaan ibadah haji di kalangan masyarakat muslim Kudus dan motifmotif mereka mengulang ibadah haji. Prosesnya berupa pengumpulan dan penyusunan data, serta analisis dan penafsiran data tersebut. Pendekatan psikologi agama dan sosial digunakan untuk melihat motif masyarakat mengulang ibadah haji dan memahami atau menginterpretasi motif dari tindakan tersebut. Artikel ini mengunakan pendekatan kualitatif yang bertujuan untuk meneliti pada kondisi obyek yang alamiah, yakni fenomena pengulangan haji masyarakat muslim Kudus. Penulis berfungsi sebagai instrumen kunci, dan analisis data bersifat induktif. Hasil metode kualitatif lebih menekankan makna daripada generalisasi. Metode fenomenologi ini dilakukan untuk mengidentifikasi dan menggambarkan fenomena psikologi pengulangan haji. Penulis memilih pendekatan fenomenologi dalam memaparkan makna pengalaman hidup individu saat melakukan pengulangan haji karena kajian ini menjelaskan pengalaman hidup informan yang dimaknai secara subjektif oleh mereka sendiri, serta mencari inti dari makna pengalaman yang dialami oleh individu.

Sumber data utama artikel ini adalah informan dari masyarakat Kudus yang pernah mengulang haji atau pernah melakukan ibadah haji lebih dari sekali tetapi bukan petugas haji. Penentuan informan hanya diperoleh dari mulut ke mulut, dalam hal ini penulis mencari info dari salah satu warga Kudus yang masih aktif dalam komunitas arisan haji, tentang warga Kudus yang pernah melaksanakan haji lebih dari sekali. Data 
tentang para pengulang haji tidak dapat diperoleh dari sumber lain, termasuk kemenag bidang haji dan umrah. Dalam hal ini penulis mendatangi rumah para informan atas saran dan informasi dari warga. Informan dalam penelitian ini berasal dari beragam kalangan, pegawai, guru, pedagang, dan wiraswasta.

Informan dipilih dengan menggunakan prosedur pengambilan sampel teoritis (theoretical sampling), dalam hal ini informan yang dipilih adalah mereka yang mampu memberikan informasi sesuai dengan fokus dan tujuan dari penelitian ini (J.W. Creswell, 1998). Artikel ini dilakukan untuk mengungkap pengulangan haji yang terjadi di tingkat lokal. Lokasi yang terpilih adalah di Kudus, Jawa Tengah. Data dalam artikel ini diperoleh dari: (1) Sumber data primer, yaitu yang melakukan pengulangan haji (2) Sumber data sekunder diperoleh dari Kasi Haji dan Umrah Kementerian Agama Kabupaten Kudus, serta berbagai literatur yang mendukung kajian ini.

Teknik pengumpulan data dilakukan melalui observasi dalam penelitian ini dilakukan secara partisipasi pasif (passive participation) (J.W. Creswell, 1998), yakni peneliti datang di tempat kegiatan orang yang diamati, tetapi tidak terlibat dalam kegiatan tersebut. Untuk meminimalisir kendala-kendala yang terjadi saat penggalian data, penulis melakukan observasi terus terang maupun tersamar kepada sumber data. Wawancara dilakukan secara semi terstruktur dan tidak terstruktur. Pertama, untuk menemukan permasalahan secara lebih terbuka, di mana pihak yang diwawancara diminta pendapat dan ide-idenya. Kedua, wawancara bebas, penulis tidak menggunakan pedoman wawancara yang telah tersusun secara sistematis dan lengkap. Wawancara dilakukan selama kurang lebih 45 menit dengan melibatkan dua orang. Jumlah informan yang berkisar antara 2 sampai 10 ini dirasa sudah cukup karena telah memenuhi persyaratan metodologi untuk sebuah kajian fenomenologi (J.W. Creswell, 1998).

Penggalian data dilakukan dengan wawancara secara intensif dan mendalam (indepth-interview) yang memfokuskan pada bagaimana pikiran, perasaan, dan tindakan informan saat melakukan pengulangan haji, latar belakang, serta motifnya (C. Moustakas, 1994). Pertanyaan terbuka (open-ended questions) yang diajukan bertujuan untuk memberikan kebebasan kepada informan dalam menjawab secara terbuka dan 
terinci tentang apa yang mereka ingin sampaikan tanpa diatur ketat oleh penulis. Dokumen dalam penelitian ini berupa buku, artikel maupun penelitian sebelumnya yang terkait dengan tema, maupun dokumen yang berbentuk gambar, dan grafik.

\section{Fenomena Berangkat Haji Masyarakat Muslim Kabupaten Kudus}

Kota Kudus dapat dipersepsikan dalam dua pandangan (Indrahti, Alamsyah, \& Maziyah, 2013). Pertama, Kudus sebagai sebuah komunitas yang lekat dengan basis sosial santri Muslim. Persepsi di atas tidak lepas dari realitas keberadaan Sunan Kudus sebagai salah satu penyebar Islam di Pesisir Utara Pulau Jawa. Artefak-artefak budaya yang diwariskan Sunan Kudus berupa sebuah komunitas santri-muslim, yang menjadi salah satu identitas kultural masyarakat Kudus. Kedua, Kudus dipersepsikan sebagai sebuah kota di Jawa Tengah yang memiliki ciri-ciri sosio ekonomi yang khas. Rokok, jenang, soto, batik, bordir, dan beberapa produk lain akan dengan mudah membawa imajinasi seseorang terhadap Kudus. Kegiatan perdagangan dan industri berbasis rumah tangga skala kecil dan menengah dan industri modern berskala besar adalah pemandangan sehari-hari bagi masyarakat Kudus.

Menyebut dan mendengar nama Kudus akan terbersit istilah Gusjigang (bagus, ngaji, dagang), yang identik penisbatannya terhadap masyarakat Kudus yang suka berdagang. Gusjigang bahkan telah menjadi citra diri masyarakat Kudus. Filosofi Gusjigang kabarnya dicetuskan oleh Sunan Kudus sang peletak dasar pertama kota Kudus. Gusjigang ini menjadi spirit dan motivasi bagai masyarakat Kudus bahwa menjadi Muslim yang baik haruslah berperilaku baik (bagus), bisa mengaji, dan pandai berdagang. Gusjigang merupakan kearifan lokal yang telah menjadi paradigma berpikir dan berperilaku masyarakat muslim di Kudus (Said, 2010, hal. 380).

Dalam bidang ekonomi, mayoritas masyarakat Kudus berprofesi sebagai pedagang. Kondisi perekonomian yang relatif baik dan stabil inilah, menurut Su'udi sebagai Kepala Seksi Haji dan Umrah Kementerian Agama Kabupaten Kudus, yang menjadikan masyarakat muslim di Kudus memiliki kemampuan untuk melaksanakan ibadah haji, bahkan ada yang mengulanginya. Jamaah haji Kudus selalu menempati rangking lima besar jumlah jamaah haji terbanyak di wilayah Jawa Tengah. Kelima besar kabupaten tersebut adalah Semarang, Pati, Demak, Kudus, dan Jepara. Lima 
kabupaten tersebut secara bergantian selalu menempati posisi peringkat atas. Bahkan Kudus pernah menempati rangking pertama jumlah jamaah haji terbanyak se propinsi Jawa Tengah. Tingginya animo masyarakat Kudus untuk melaksanakan ibadah haji karena faktor Kudus sebagai masyarakat industri yang menyebabkan mereka memiliki kemapanan ekonomi.

Selain itu, kondisi sosial keagamaan masyarakat Kudus yang mayoritas beragama Islam dan organisasi keagamaan Nahdlatul Ulama (NU) juga menjadi faktor penyebab tingginya animo masyarakat melaksanakan ibadah haji. Menurut Su'udi, masyarakat NU memiliki persepsi bahwa kesempurnaan haji dapat dicapai dengan mengulangi pelaksanaanya. Semakin sering melaksanakan ibadah haji, maka semakin sempurna pula hajinya. Hal ini dinyatakan Su'udi berdasarkan ungkapan para jamaah calon haji yang mendaftar di Kemenag Kabupaten Kudus.

Fenomena terus meningkatnya jumlah jamaah haji dan adanya pengulangan haji oleh sebagian masyarakat muslim Kudus cukup menarik untuk dikaji. Apakah gejala tersebut merupakan indikator tingginya ketakwaan dengan melaksanakan rukun Islam kelima dan kualitas keberagamaan (religiusitas) masyarakat muslim Kudus yang cenderung membaik. Atau justru fenomena tersebut merupakan indikator stabilitas dan kemampuan ekonomi masyarakat muslim Kudus, mengingat bahwa ibadah haji termasuk ibadah ekslusif yang membutuhkan biaya paling mahal (Firdaus, 2017, hal. 55). Biaya haji saat ini tidak hanya untuk operasional haji selama di Makkah, tetapi juga untuk biaya di luar itu. Warga masyarakat Kudus yang telah melaksanakan ibadah haji menyatakan bahwa orang yang hendak berhaji juga harus menyiapkan anggaran pra dan pasca pelaksanaan haji.

Biaya operasional pra haji digunakan untuk tasyakuran, sejenis acara selametan dengan memasak beberapa jenis menu makanan, kue, dan rokok yang nantinya disediakan bagi para tamu yang datang. Tamu berasal dari berbagai kalangan, yakni tetangga, teman karib, teman kantor, handai taulan dan pihak lain yang memiliki ikatan pertemanan maupun persaudaraan. Semakin tinggi status sosial dan status pekerjaan seseorang, maka tamu yang datang semakin banyak. Tamu yang datang bisa berjumlah ratusan, ada acara khusus yang dilaksanakan untuk menghantar warga masyarakat yang 
hendak berangkat haji. Acara tersebut berupa forum resmi karena ada MC (Master of Ceremony), pembacaan ayat suci al-Quran, sambutan, doa, dan pengumandangan adzan.

Sementara itu, sepulang dari haji masih diperlukan anggaran untuk membeli oleh-oleh berupa makanan maupun barang bagi sanak saudara maupun para tamu yang nantinya akan datang ke rumah untuk ngalap berkah. Tamu-tamu yang datang secara bergantian selama empat puluh hari. Masyarakat meyakini bahwa orang yang telah berhaji doanya maqbul, karenanya para tamu selalu meminta doa. Hal ini dituturkan oleh Bapak M yang selalu hadir di rumah orang yang baru pulang haji. Bapak M meyakini bahwa kehadirannya untuk ngalap berkah haji suatu saat akan membawanya ke Makkah. Hal ini dibuktikan dengan pelaksanaan haji yang sudah Bapak M lakukan sebanyak dua kali. Tamu yang datang disuguhi makanan khas arab, seperti kurma, kacang arab, air zam-zam. Para tamu pulang dengan membawa oleh-oleh dari tuan rumah berupa sajadah, jilbab, sarung, tasbih, mukena, minyak wangi, dan aksesoris arab lainnya. Kualitas barang tergantung kondisi ekonomi sang tuan rumah. Semakin tinggi kapasitas ekonomi dan status sosial orang yang berangkat haji, maka oleh-oleh barang yang diberikan kepada tamu juga semakin bagus dan mahal harganya.

Dua tradisi masyarakat muslim Kudus dalam pelaksanaan ibadah haji, baik sebelum maupun sepulang dari Makkah, konon membutuhkan biaya yang lebih mahal dibanding biaya haji itu sendiri. Bahkan ada fenomena warga yang menjual sebagian hak miliknya, berupa tanah, sawah, dan barang berharga lainnya yang digunakan untuk biaya haji. Pengorbanan yang luar biasa tersebut menjadi menarik jika dikaitkan dengan normatifitas haji yang hanya berlaku bagi orang yang mampu secara fisik maupun finansial. Apakah pengorbanan warga yang hendak berhaji semata-mata demi meraih ridla Allah atau ada motif dan tujuan lain yang menyebabkan mereka berani dan rela melakukannya?

Pengorbanan material yang dilakukan warga masyarakat Kudus yang melaksanakan ibadah haji dapat dikaitkan dengan makna haji bagi mereka. Pemaknaan haji mereka peroleh berdasarkan pengalaman pribadi selama berhaji di Makkah maupun dari orang lain. Pengalaman haji selalu menjadi bahan pembicaraan hangat 
dalam forum silaturahmi sepulang dari haji. Orang yang pulang dari haji akan menceritakannya kepada para tamu yang datang ke rumahnya, baik beragam peristiwa yang dialami secara langsung maupun orang lain. Haji dimaknai sebagai miniatur akhirat, sehingga apapun kebaikan dan keburukan yang dilakukan sebelum ataupun selama haji akan langsung mendapat balasan. Selama berhaji orang harus ekstra hatihati menjaga hati, pikiran, sikap dan tutur kata. Bahkan hal baik maupun buruk yang terdetik dalam benak dan belum diwujudkan pun sudah mendapat balasan dari Allah swt.

Haji juga dimaknai sebagai momen penting untuk menghaturkan doa sebanyakbanyaknya karena di Makkah banyak tempat mustajabah. Masyarakat muslim Kudus yang hendak berangkat haji selalu mempersiapkan doa dan permohonan yang kelak dimintakan di Makkah. Bahkan calon jamaah haji juga bersedia menerima titipan doa dan permohoan dari orang lain. Ibu S menuturkan bahwa banyak teman dan kerabatnya yang menitipkan doa dan permohonan kesembuhan dari sakit, ekonomi yang meningkat, memperoleh keturunan, menemukan jodoh dan lainnya. Nama dan harapan-harapannya ditulis dalam secarik kertas. Kertas yang berisi nama-nama orang yang menitipkan doa tersebut akan ditanam dan dikubur saat Wukuf di Arafah. Mereka meyakini doa-doa yang diminta oleh orang-orang tersebut akan terkabul.

Konsep masyarakat muslim Kudus dalam memandang haji ada dua hal (Sulthoni \& Muhlisin, 2013), yakni berkah dan peningkatan kualitas ekonomi. Berkah dalam artian bahwa kemampuan dan kemauan untuk berhaji adalah fadhal dari Allah swt. Harta yang berlebih dan melimpah terkadang diiringi dengan rasa enggan bagi pemiliknya kemauan menyisihkannya dan menganggarkannya untuk berhaji. Sebaliknya, harta yang cukup justeru diiringi pemiliknya untuk menggunakannya mendaftar haji. Bagi mereka harta yang berkah bukan dari kuantitasnya, tetapi lebih pada fungsinya untuk mendekatkan dan menjadi "tamu" Allah dengan berhaji. Jadi, kemampuan melaksanakan ibadah haji merupakan fadhal (anugerah) Allah yang menjadi salah satu indikator keberkahan harta yang dimiliki.

Konsep lain yang dipahami masyarakat muslim Kudus dalam memandang haji adalah peningkatan kualitas ekonomi. Dalam hal ini haji berfungsi sebagai motivasi 
untuk mengembangkan kualitas ekonomi. Masyarakat meyakini bahwa harta yang telah dikeluarkan untuk biaya haji akan diganti dan dilipatgandakan oleh Allah swt. Sebagaimana yang disampaikan oleh ibu S bahwa ia justru bisa mengganti mobil lamanya dengan membeli mobil baru sepulang dari haji. Menurut penuturan ibu S, harta yang dilipatgandakan oleh Allah adalah jika dana yang digunakan untuk berhaji berasal dari jerih payah pribadi, yakni berupa rezeki yang semakin bertambah sepulang berhaji. Hal serupa juga disampaikan oleh ibu $M$ yang merasakan wirausahanya membuat gado-gado (keripik kentang pedas) semakin lancar dan pelanggannya bertambah setelah berhaji. Bahkan saat ini karyawannya semakin bertambah banyak. Karyawan ibu M berasal dari kalangan janda-janda paruh baya di sekitar rumahnya. Meskipun secara kuantitas, produktifitas mereka kalah dengan kaum muda, namun hal itu tidak mengurangi keinginan ibu $M$ untuk tetap memberdayakan mereka karena alasan kemanusiaan.

\section{Haji Dua Kali: Analisis Motif Pengulangan Haji di Kalangan Masyarakat Muslim Kudus}

Para informan menyatakan motif mengulang haji secara beragam. Semua informan telah melakukan haji dua kali. Informan mengulang haji di saat pemerintah Indonesia belum mengeluarkan kebijakan tentang ketentuan berhaji bagi pihak yang telah dan pernah berhaji. Hal ini bukan berarti mengetahui dan menganalisis motif mengulang haji menjadi tidak penting, karena para informan tidak ada yang menyebutkan alasan karena belum adanya kebijakan bagi para pengulang haji. Justru pengulang haji berasal dari motif mereka secara pribadi (instrinsik) bukan dari pihak lain. Motif para pengulang haji akan dideskripsikan dalam paragraf-paragraf berikut. Keenam informan dalam narasi berikut akan diberi kode X1, X2 dan seterusnya.

Informan X1 dan X2 adalah sepasang suami isteri yang telah melaksaakan ibadah haji sebanyak dua kali, pada tahun 1998 dan 2000. Haji yang pertama dibiayai oleh putra mereka yang telah sukses secara material. Sang putera ingin menunjukkan bakti kepada orang tuanya dengan mendaftarkan haji. Bagi sang putra, kemampuan menghajikan orang tua merupakan cita-citanya jika sukses kelak. Namun dalam hal ibadah haji, orang tua (X1\&X2) justeru merasa belum dianggap mampu (istitha'ah) 
sebagaimana isyarat al Quran tentang anjuran berhaji. Bagi X1\&X2, haji berlaku hanya bagi orang yang mampu terutama materi. Oleh karenanya, haji pertama dirasa belum sempurna karena biayanya tidak berasal dari jerih payah mereka, sehingga perlu dilaksanakan pengulangan haji dengan biaya dari mereka sendiri, bukan dari orang lain. Berhaji dengan menggunakan biaya sendiri menimbulkan kepuasan batin dan perwujudan eksistensi diri bahwa mereka telah memenuhi standar istitha'ah yang termaktub dalam ayat al Quran tentang anjuran haji. Dengan demikian predikat haji yang diperoleh telah dianggap sah karena telah memenuhi kriteria melaksanakan haji.

Informan X3 adalah seorang perempuan eks pekerja seks komersial (PSK) yang juga telah berhaji sebanyak dua kali. Pada saat melaksanakan haji pertama, banyak ritual haji yang tidak bisa dilaksanakan karena terhalang menstruasi hingga ibadah haji berakhir (haji wada'). Informan X3 merasa tidak puas dengan ibadah haji pertamanya. Ia merasa ibadah haji pertamanya jauh dari kategori sempurna, yang tentunya tidak akan mampu menghapus dosanya. Rasa tidak puas ini menjadi motivasinya untuk berniat dan bertekad melaksanakan haji yang kedua kali untuk meraih kesempurnaan haji dan bisa mendapat ampunan dari Allah sekembali dari haji.

Informan X4 dan X5 sepasang suami isteri yang berprofesi sebagai guru berstatus Aparatur Sipil Negara (ASN) atau pegawai negeri. Sang suami berusia 10 tahun lebih tua dibanding isterinya. Selisih usia yang relatif banyak inilah yang membuat bapak X4 terdorong untuk segera melaksanakan ibadah haji di tahun 2008, karena khawatir jika sewaktu-waktu Allah mengambil nyawanya sementara ia belum sempat berhaji. Selain itu, bapak X4 ingin berhaji mendahului istrinya agar ia mengetahui dan menguasai tentang ritual ibadah haji dan teknis pelaksanaannya, juga tempat-tempat di Makkah yang digunakan untuk melaksanakan beragam ritual haji. Dengan demikian bapak X4 nantinya akan dapat membimbing, memandu dan mendampingi isterinya saat melaksanakan ibadah haji. Pada tahun 2010 pasangan tersebut mendaftar haji dan berangkat di tahun 2013. Bagi bapak X4 haji di tahun 2013 merupakan haji kedua.

Bapak X4 adalah seorang warga Kudus yang rajin melaksanakan shalat berjamaah di masjid. Ketika peneliti dua kali berkunjung ke rumahnya untuk 
mengadakan interview, bapak X4 masih shalat berjamaah shalat ashar. Ibu X5 menyatakan bahwa bapak X4 adalah pribadi yang istiqamah dalam beribadah. Bapak X4 sangat rutin menghadiri ziarah tasyakuran haji dan senantiasa berdoa agar suatu saat bisa melaksanakan ibadah haji. Selain berprofesi sebagai guru, pasangan ini merintis wirausaha sambal goreng kering sejak tahun 1994 sebagai penghasilan sampingan. Karena pada saat itu gaji guru masih sangat rendah. Bagi pasangan bapak X4 dan ibu X5, melaksanakan ibadah haji dengan tidak menggunakan dana talangan haji membuat mereka lebih puas dan menjadikan haji lebih diberkahi dan diridlai Allah. Pada saat berangkat haji yang pertama, waiting list atau daftar tunggu haji maksimal 5 tahun dan belum ada kebijakan pemerintah tentang larangan mengulang haji bagi jamaah yang pernah melaksanakan ibadah haji.

Informan X6 berprofesi sebagai pensiunan kepala rumah sakit umum daerah (RSUD) Kabupaten Kudus. Bapak X6 melaksanakan ibadah haji pertama pada tahun 1979, karena diminta ibunya menemani dan mendampingi berhaji. Bapak X6 memiliki saudara berjumlah tujuan orang yang terdiri dari tiga orang laki-laki dan empat orang perempuan. Bapak X6 dipilih oleh ibunya sebagai pendamping haji dengan alasan bapak X6 dipandang paling shaleh dan rajin mengaji dibanding saudaranya yang lain. Saat itu statusnya masih mahasiswa dan belum menikah. Saat menjabat sebagai kepala RSUD Kudus bapak X6 dikenal sebagai sosok pribadi yang baik kepadan karyawan, nrimo (pandai bersyukur) dan apa adanya (tidak neko-neko). Bapak X6 juga sosok yang rajin dan aktif dalam kegiatan sosial keagamaan, majelis ta'lim, hidup sederhana dan sangat bersahaja. Menurut bapak X6, keinginan dan kemampuan melaksanakan ibadah haji merupakan fadhal Allah, artinya memang Allah yang menghendaki (dikersakke) dan meridlai. Hal inilah yang membuat bapak X6 dapat melaksanakan ibadah haji untuk kedua kali bersama isterinya di tahun 2005. Menurut bapak X6 berangkat haji sarimbit (bersama istri) adalah cita-cita mereka sejak menikah. Bagi mereka bisa berangkat haji berdua adalah kebahagiaan yang sangat berharga.

Informan ibu X7 berprofesi sebagai guru bahasa Inggris di salah satu madrasah ternama di Kudus. Ibu X7 melaksanakan ibadah haji yang pertama di tahun 1995. Saat itu statusnya sudah menikah. Pelaksanaan haji pertamanya dilakukan sendiri tanpa suami. Menurutnya ada rasa kurang puas saat berhaji tanpa didampingi suami. 
Kebahagiaan puncak bagi ibu X7 adalah dapat melaksanakan haji bersama suami. Haji yang dilaksanakan lebih sempurna. Karena alasan ini ibu X7 termotivasi untuk mendaftar dan mengulang haji pada tahun 2005. Pada saat itu terdapat sedikit kendala dalam hal kuota keberangkatan haji. Kondisi ini sangat memungkinkan bagi ibu X7 untuk gagal berangkat haji bersama suaminya. Namun ibu X7 tidak menyerah begitu saja. Ia siap klarifikasi dan konfirmasi ke Departemen Agama (saat ini berubah menjadi Kementerian Agama) untuk memperjuangkan suaminya agar tetap bisa berangkat haji bersama suami sebagaimana yang telah mereka rencanakan. Setelah berjuang dan berusaha secara maksimal, akhirnya ibu X7 dipastikan dapat berhaji bersama suaminya. Kesempatan untuk dapat berhaji bersama suami, bagi ibu X7 adalah "fadhal" Allah. Orang yang kaya dan banyak uang belum tentu mau dan bisa melaksanakan ibadah haji atau sebaliknya.

Manusia mempunyai potensi untuk memberi arah dalam kehidupan manusia. Potensi tersebut adalah hidayat al-ghariziyyat (naluriah), hidayat al-hissiyat (inderawi), hidayat al-aqliyyat (nalar) dan hidayat al-diniyyat (agama). Berdasarkan pendekatan ini, agama sudah menjadi fitrah manusia yang dimiliki sejak lahir. Pengaruh lingkungan terhadap seseorang adalah memberikan bimbingan kepada potensi tersebut. Dalam hal ini pengaruh agama dalam kehidupan individu adalah memberi kemantapan batin, rasa bahagia, rasa terlindung, rasa sukses, dan rasa puas. Perasaan positif ini selanjutnya akan menjadi pendorong (motif) untuk berbuat. Agama dalam kehidupan individu selain menjadi motivasi dan nilai etik juga merupakan harapan (Jalaluddin, 2015).

Agama berpengaruh sebagai motivasi dalam mendorong individu untuk melakukan suatu aktifitas, karena perbuatan yang dilakukan dengan latar belakang keyakinan agama dinilai menjadi unsur kesucian dan ketaatan. Keterkaitan ini akan memberi pengaruh pada diri seseorang untuk berbuat sesuatu. Sedangkan agama sebagai nilai etik karena dalam melakukan sesuatu tindakan seseorang akan terikat kepada ketentuan antara mana yang boleh dan mana yang tidak boleh menurut ajaran agama yang dianutnya (Jalaluddin, 2015). Sebaliknya agama juga sebagai pemberi harapan bagi pelakunya. Seseorang yang melaksanakan perintah agama umumnya karena adanya suatu harapan terhadap pengampunan atau kasih sayang dari sesuatu yang gaib (supranatural). Motivasi mendorong manusia untuk berkreasi, berbuat 
kebajikan maupun berkorban. Sedangkan nilai etik mendorong seseorang untuk berlaku jujur, menepati janji, dan menjaga amanat. Sedangkan harapan mendorong orang untuk bersikap ikhlas, menerima cobaan yang berat ataupun berdoa. Sikap seperti itu akan lebih terasa secara mendalam jika bersumber dari keyakinan terhadap agama (Jalaluddin, 2015).

Motivasi seseorang dalam melakukan sesuatu hal dapat diketahui dengan melihat fungsional dari haji yang dijalankan. Berdasarkan fungsionalisasi haji yang dilakukan masyarakat Muslim Kudus, dapat diketahui bahwa haji yang mereka laksanakan tidak hanya berupa motif keagamaan saja, tetapi juga psikologis dan ekonomi. Motif melaksanakan haji berbasis religius adalah spirit yang terkandung pada orang yang melaksanakan ibadah haji karena semata-mataingin mendekatkan diri kepada Allah, lebih menguatkan ketakwaan dan iman, serta bertujuan ingin menyempurnakan rukun Islam yang kelima. Beda halnya dengan motivasi haji berbasis ekonomi, hal ini lebih dilakukan karena ingin sepulang dari haji usahanya semakin maju dan lancar, juga semakin dipercaya oleh para konsumen (Firdaus, 2017).

Pemahaman dari perspektif psikologi terhadap pengulangan ibadah haji yang dilaksanakan yakni ibadah haji dimaknai sebagai spirit beribadah karena merasa menjadi makhluk dan pribadi yang suci dan bersih bahkan dapat menggapai kesempurnaan diri dengan cara mengulang-ulang hajinya. Haji dimaknai sebagai ritual penebus dosa sehingga semakin sering dilakukan maka dosa-dosa masa lalu dapat terhapus. Kesempurnaan haji hanya dapat diraih dengan melaksanakan semua ritualnya. Jika ada satu ritual haji yang belum bisa terlaksana karena kendala dan halangan tertentu, maka predikat haji mabrur otomatis akan gugur. Oleh karenanya perlu dilaksanakan pengulangan haji pada tahun-tahun berikutnya untuk meraih kemabruran.

Haji juga dimaknai sebagai puncak cita-cita, kebahagiaan tertinggi, terlebih jika mampu berhaji dengan pasangan hidup. Sebuah kepuasan jika bahtera rumah tangga dapat berlabuh dalam ritual haji yang menjadi dambaan banyak orang. Bagi pasangan tersebut, kebersamaan dalam beribadah haji menjadi bagian dari manifestasi rasa sakinah, mawaddah, dan rahmah. Karenanya, beragam upaya dan pengorbanan harus 
dilakukan untuk meraihnya. Bahkan jika salah satu pasangan gagal pergi haji karena faktor kesehatan, usia, dan lainnya, maka sang isteri atau suami rela membatalkan hajinya dengan alasan merasa tidak sreg dan tidak puas jika berangkat haji tanpa pasangan. Sebagaimana bapak M yang mengawali haji pertamanya agar dapat mendampingi dan membimbing isterinya untuk melaksanakan haji di tahun yang akan datang. Dengan berhaji lebih dahulu, tentunya seluk beluk tentang Makkah dan ritualnya akan mudah dikuasai. Pengulangan haji bapak $M$ dilakukan dalam rangka menjadi penunjuk dan pendamping isterinya agar tidak tersesat selama melaksanakan haji di Makkah.

Bagi sebagian orang memang agama itu soal rasa (Mawardi, 2016, hal. 222), dengan orang memahami makna kasih, kemurahan, dan keadilan Allah swt. Dengan rasa orang berserah diri, takwa dan tawakal kepadaNya. Penghayatan dan perilaku keagamaan yang dipengaruhi rasa, akhir-akhir ini bisa ditemukan dalam pelaksanaan ritual beragama termasuk haji. Perkara rasa dan rasio, sebenarnya merupakan dua sisi dari sekeping mata uang dalam agama. Artinya, agama menuntut kehadiran duaduanya secara utuh dalam tiap pribadi. Sehingga tidak diperlukan sikap untuk mengutamakan satu dan mengabaikan yang lain. Jika dalam diri seseorang ada kecenderungan lebih mengutamakan rasa, mungkin tidak sangat buruk asalkan rasa tersebut tidak lantas anti intelektualitas. Harus disadari bahwa rasalah yang membuat hubungan manusia dengan Allah menjadi hangat, intim, dan mempribadi. Rasio juga bagus asalkan tidak dominan berlebihan. Rasio memang mengontrol tingkah laku keagamaan agar tidak gentayangan kemana-mana sekedar memenuhi suruhan rasa. Tapi rasio juga bisa menjerumuskan manusia ke dalam sumur kering penghayatan, dangkal, formalistis, asal sah tapi tanpa nuansa, tanpa getaran rasa.

Ibadah haji bagi masyarakat, dalam hal ini, berfungsi sebagai edukatif, penyelamat, pendamai, social control, pemupuk rasa solidaritas, transformatif, kreatif dan sublimatif dan motivasi bermakna (Jalaluddin, 2015). Kendati pada dataran fenomenanya, sebagian masyarakat memasukkan fungsi ibadah haji ke wilayah material, seperti peningkatan ekonomi, status sosial, mendapat jodoh, memperoleh keturunan, kesembuhan dari penyakit berat dan lain-lain.Fungsi ibadah haji yang semakin kompleks inilah yang menyebabkan masyarakat rela berjuang dan berkorban untuk 
dapat melaksanakan haji. Bahkan perjuangan dan pengorbanan tersebut dilakukan dengan cara apapun, dengan menjual sawah, tanah, mengikuti dana talangan haji, arisan haji dan lainnya.

Manfaat ibadah haji yang disebutkan dalam hadis nabi bahwa melaksanakannya dapat menghapus dosa, masuk surga dan mendapat imbalan harta pengganti biaya haji menjadi daya tarik tersediri bagi masyarakat muslim. Manfaat-manfaat tersebut menjadi tujuan menarik, yang menyebabkan individu atau masyarakat lebih antusias melaksanakan haji. Kendati tujuan-tujuan yang termaktub dalam hadis tersebut berupa obyek yang abstrak. Berdasarkan teori harapan Vroom, individu, dan masyarakat muslim di wilayah tertentu memiliki motivasi dan animo yang tinggi melaksanakan pengulangan ibadah haji karena mereka percaya bahwa perilaku mengulang haji akan menghasilkan kesempurnaan haji dari pelaksanaan haji sebelumnya, dosa-dosanya akan diampuni dan dapat masuk surge (Toguslu, 2017). Ketiganya merupakan tujuan tertinggi umat Islam, sehingga ibadah haji menjadi salah satu ritual penghapus dosa yang banyak diminati umat Islam, kendati dengan pengorbanan harta yang ekstra mahal dibanding pelaksanaan ritual ibadah yang lain. Seseorang lebih cenderung memilih ibadah haji karena mereka meyakini besarnya manfaat ibadah haji, ditambah lagi dengan daya tarik ritual dan tempat-tempat mustajab di Makkah. Ibadah haji bagi masyarakat mengandung banyak keajaiban nyata yang dampaknya bisa langsung dirasakan. Sehingga hal ini semakin menambah motivasi untuk terus mengulang ibadah yang ekstra spesial ini.

Dalam prespektif psikologi, daya pendorong untuk terus melakukan sesuatu merupakan dampak adanya virus mental. Dalam konteks tersebut, boleh jadi perilaku mengulang haji merupakan virus mental yang telah berjangkit dalam jiwa masyarakat muslim (Shobur, 2003). Virus mental tersebut yang menjadi daya dalam mental masyarakat Muslim untuk melakukan kegiatan (ibadah) yang bermanfaat bagi kehidupan di dunia maupun akhirat, yakni kebutuhan untuk berprestasi, baik di hadapan Allah swt maupun di hadapan manusia. Hal ini berdasarkan asumsi bahwa mayoritas masyarakat masih memandang status haji sebagai status sosial yang tinggi. Kemampuan melaksanakan ibadah haji dianggap masyarakat sebagai prestasi yang sangat tinggi, bahkan dimaknai sebagai puncak prestasi selama hidup di dunia. Oleh 
karenanya, orang yang telah melaksanakan ibadah haji diperlakukan istimewa dalam suatu komunitas. Hal ini menjadi salah satu sebab munculnya fenomena antrian haji (waiting list) yang sangat panjang bahkan hingga puluhan tahun.

Sedangkan sudut pandang teori harapan (expectancy theory) yang dikembangkan oleh Vroom, masyarakat Kudus percaya bahwa dapat mengulang haji merupakan fadhal Allah sebagai wadah mereka untuk mewujudkan segala harapan duniawi maupun ukhrawi. Harapan duniawi terkait dengan hal-hal yang bersifat fisikmaterial seperti mendapat jodoh, sembuh dari penyakit, cita-cita tercapai, bertambahnya harta, keharmonisan hubungan keluarga bahkan ketenangan pikiran dan jiwa. Sedangkan harapan ukhrawi terkait dengan hal-hal yang bersifat non fisikimmaterial seperti mendapat kesempurnaan iman, kesucian diri karena terhapus segala dosa, hingga pahala dapat masuk surga. Dampak nyata dari ibadah haji, baik di saat sedang proses berhaji maupun sesudahnya, mampu menjadi daya tarik tersendiri bagi masyarakat Kudus untuk mengulang ibadah hajinya. Kesan-kesan positif yang telah dialami selama haji, semakin memperkuat dorongan untuk dapat mengulanginya kembali dengan berhaji yang kedua dan seterusnya. Meskipun masyarakat Kudus sadar bahwa berhaji memerlukan biaya besar, tenaga dan upaya yang optimal. Namun, hal tersebut menjadi tidak berarti dibandingkan dengan hasil dan dampak berhaji yang luar biasa.

Sejatinya, berdasarkan teori kebutuhan berprestasi dalam Islam, orang beribadah bukan untuk mencari pengakuan dari orang lain, tetapi mendapat pengakuan dari Allah swt. Pencarian pengakuan dari manusia atas prestasi yang dapat mengantarkan seseorang pada ketidakpuasan yang menjadi sumber ketegangan jiwa. Berpegang pada teori kebutuhan berprestasi yang islami, manusia akan dapat menikmati ibadahnya dan dapat meningkatkan kualitas ibadah dan hidupnya tanpa disertai dampak yang sangat merugikan kesejahteraan manusia (Jalaluddin, 2015). Perilaku pengulangan haji juga termasuk bertujuan untuk memenuhi kebutuhan aktualisasi diri (self-actualization needs), karena aktualisasi diri dapat diwujudkan dalam berbagai aktifitas, termasuk mengulangi haji. Berhaji dan mengulanginya untuk yang kedua ketiga dan seterusnya merupakan bagian dari hasrat untuk menjadi diri sepenuh kemampuannya sendiri karena kebutuhan-kebutuhan lainnya telah terpenuhi. Berhaji 
dan mengulanginya sebagai kebutuhan aktualisasi diri tidaklah mudah, karena tentu membutuhkan optimalisasi dana, tenaga, pikiran dan fisik. Haji membutuhkan dana besar, fisik yang sehat dan tenaga yang kuat untuk dapat melaksanakan beragam ritual haji di tengah lautan manusia dan terik matahari. Persiapan dan pelaksanaan haji sangat menguras pikiran. Motif pengulangan haji oleh masyarakat Muslim Kudus disajikan dalam tabel 1 .

Tabel 1 Motif Pengulangan Haji Masyarakat Muslim Kudus

\begin{tabular}{|c|c|c|c|}
\hline Informan & Motif Mengulang Haji & Teori Harapan & Klasifikasi Motif \\
\hline $\mathrm{X} 1$ & $\begin{array}{l}\text { Ingin berhaji menggunakan biaya } \\
\text { sendiri, bukan dibiayai orang lain, } \\
\text { termasuk anak. Biaya haji yang } \\
\text { mendapat ganti dari Allah adalah haji } \\
\text { dengan biaya sendiri, bukan dana } \\
\text { talangan. }\end{array}$ & $\begin{array}{l}\text { Harapan } \\
\text { Usaha (Effort } \\
\text { Expectacy) }\end{array}$ & $\begin{array}{l}\text { Motif sekunder, motif } \\
\text { bergabung, motif sekunder } \\
\text { mendekat, motif sadar dan } \\
\text { motif sosiogenetis- } \\
\text { teogenetis }\end{array}$ \\
\hline $\mathrm{X} 2$ & $\begin{array}{l}\text { Haji pertama dibiayai orang lain, } \\
\text { karena itu harus berhaji lagi untuk } \\
\text { meraih kesempurnaan haji }\end{array}$ & $\begin{array}{l}\text { Harapan Hasil } \\
\text { (Outcome } \\
\text { Expectacy) }\end{array}$ & $\begin{array}{l}\text { Motif sekunder, motif } \\
\text { bergabung, motif sekunder } \\
\text { mendekat, motif sadar dan } \\
\text { motif sosiogenetis- } \\
\text { teogenetis }\end{array}$ \\
\hline $\mathrm{X} 3$ & $\begin{array}{l}\text { Haji pertama banyak ritual yang tidak } \\
\text { terlaksana karena menstruasi yang } \\
\text { terus menerus, sehingga khawatir jika } \\
\text { dosa-dosanya di masa lalu tidak } \\
\text { terampuni. Karena itu harus } \\
\text { dilakukan pengulangan haji. }\end{array}$ & $\begin{array}{l}\text { Harapan } \\
\text { Usaha (Effort } \\
\text { Expectacy) }\end{array}$ & $\begin{array}{l}\text { Motif sekunder, motif } \\
\text { bergabung, motif sekunder } \\
\text { mendekat, motif sadar dan } \\
\text { motif teogenetis }\end{array}$ \\
\hline $\mathrm{X} 4, \mathrm{X} 5$ & $\begin{array}{l}\text { Ingin berhaji bersama pasangan. } \\
\text { Berhaji bersama isteri adalah } \\
\text { kebahagiaan tertinggi }\end{array}$ & $\begin{array}{l}\text { Harapan } \\
\text { Usaha (Effort } \\
\text { Expectacy) }\end{array}$ & $\begin{array}{l}\text { Motif sekunder, motif } \\
\text { bergabung, motif sekunder } \\
\text { mendekat, motif sadar dan } \\
\text { motif sosiogenetis- } \\
\text { teogenetis }\end{array}$ \\
\hline $\mathrm{X} 6$ & $\begin{array}{l}\text { Haji pertama dibiayai orangtua. } \\
\text { Karenanya perlu mengulang haji } \\
\text { dengan biaya sendiri }\end{array}$ & $\begin{array}{l}\text { Harapan } \\
\text { Usaha (Effort } \\
\text { Expectacy) }\end{array}$ & $\begin{array}{l}\text { Motif sekunder, motif } \\
\text { bergabung, motif sekunder } \\
\text { mendekat, motif sadar dan } \\
\text { motif sosiogenetis- } \\
\text { teogenetis }\end{array}$ \\
\hline $\mathrm{X} 7$ & $\begin{array}{l}\text { Haji pertama belum bersama } \\
\text { pasangan, karenanya perlu } \\
\text { mengulang haji dengan berhaji } \\
\text { bersama pasangan untuk menambah } \\
\text { keharmonnisan keluarga }\end{array}$ & $\begin{array}{l}\text { Harapan } \\
\text { Usaha (Effort } \\
\text { Expectacy) }\end{array}$ & $\begin{array}{l}\text { Motif sekunder, motif } \\
\text { bergabung, motif sekunder } \\
\text { mendekat, motif sadar dan } \\
\text { motif teogenetis }\end{array}$ \\
\hline
\end{tabular}


Motif pengulangan haji masyarakat Muslim Kudus didominasi oleh asumsidan penilaian subyektif bahwa perilaku mengulang haji dipercaya dapat mewujudkan segala harapan. Seseorang atau masyarakat yang termotivasi untuk berhaji, maka yang bersangkutan akan berusaha keras untuk melaksanakan sesuatu atau usaha. Terdapat beberapa karakteristik motivasi. Pertama, adanya individu sebagai aktor. Kedua, aktor dipandang sebagai pemburu tujuan-tujuan tertentu. Ketiga, mempunyai alternatif cara, alat serta teknik untuk mencapai tujuannya. Keempat, aktor berhadapan dengan sejumlah kondisi situasional yang dapat membatasi tindakannya dalam mencapai tujuan. Kelima, aktor berada di bawah kendali dari nilai-nilai, norma-norma dan berbagai ide abstrak yang mempengaruinya dalam memilih dan menentukan tujuan serta tindakan alternatif untuk mencapai tujuan. Berdasarkan konsepsi fenomenologi maka dipastikan ada in order motives yang menjadi basis bagi tindakan masyarakat Kudus mengulang haji. Secara sosiologis tindakan sosial dibentuk dan dimaknai melalui simbol yang dipahami oleh masing-masing individu atau kelompok dalam masyarakat. Kendati kemampuan menangkap dan memaknai simbol itu bersifat personal, namun setiap orang memiliki keinginan yang sama dalam kehidupannya, yaitu keinginan untuk memperoleh berkah dan keselamatan (Suryana, 2013, hal. 22).

Hartini (2016) menegaskan bahwa dalam sepuluh tahun terakhir ini praktik haji dan umrah nampaknya terus mengalami pertumbuhan pesat dan menjadi praktik yang meluas di masyarakat Makassar. Hal ini merupakan dampak kondisi pertumbuhan ekonomi yang cukup tinggi dan meningkatnya apresiasi terhadap gaya hidup religius telah menjadi konteks yang mengkondisikan praktik ini lahir dan berkembang di Makassar. Nampaknya fenomena serupa juga merambah berbagai wilayah di Indonesia, termasuk pada masyarakat muslim di Kabupaten Kudus Jawa Tengah. Tahir (Tahir, 2016) mensinyalir munculnya gejala sosial-keagamaan di Indonesia yang sedang marak terjadi beberapa tahun terakhir ini. Gejala tersebut adalah semakin maraknya perusahaan dan asosiasi travel yang menyelenggarakan jasa perjalanan haji dan umrah. Masyarakat pengguna jasa tersebut juga semakin banyak. Hal ini mengindikasikan bahwa minat masyarakat kelas menengah muslim terus tumbuh.

Umaiyah (2009) juga memfokuskan pada motif sosial yang melatarbelakangi masyarakat Desa Umbulmartani di Kecamatan Ngemplak Sleman Yogyakarta 
menunaikan Ibadah haji dan pandangan terhadap haji. Kenyataan besarnya minat masyarakat Umbulmartani menunaikan Ibadah haji tidak dapat dipungkiri merupakan suatu hal yang menarik perhatian. Mengingat di satu pihak Ibadah haji sangat bergantung pada kemampuan finansial seorang Muslim yang dikenal dengan ongkos naik haji yang relatif mahal. Sedangkan di lain, pihak taraf kehidupan ekonomi masyarakat Umbulmartani masih relatif rendah dibanding dengan daerah-daerah lain. Ditemukan fakta bahwa animo masyarakat tentang ibadah haji itu sangat tinggi, karena masyarakat mempunyai anggapan bahwa ibadah haji memberikan arti penting terhadap kehidupan secara lebih dibandingkan dengan masyarakat yang belum menunaikan ibadah haji. Misalnya, anggapan bahwa orang yang telah menunaikan Ibadah haji akan mendapatkan kehormatan tersendiri di dalam masyarakat, menjadi bagian yang paling penting di masyarakat dan lebih mendapatkan kepercayaan di masyarakat. Hal tersebut yang kebanyakan menjadi faktor masyarakat dalam menunaikan ibadah haji. Selain itu pandangan masyarakat tentang ibadah haji adalah anggapan bahwa masyarakat yang menunaikan ibadah haji mendambakan dirinya meraih predikat haji mabrur.

Gelar atau predikat haji telah menjadi status sosial, hal itu disebabkan karena orang yang berhaji dianggap orang yang saleh yang telah menyempurnakan agamanya, dan secara ekonomi kaya atau lebih dari cukup. Masih ada faktor-faktor yang melatarbelakngi minat masyarakat menunaikan ibadah haji selain dari pada faktor ekonomi dan sosial yakni faktor teogenetis, faktor yang timbuldari interaksi antara individu dengan Tuhannya, juga faktor sosiogenetis, faktor yang timbul dari dalam diri individu dan berhubungan dengan lingkungan sosial. Haji dalam masyarakat Sasak juga tidak hanya dijadikan sebagai suatu aktualisasikepatuhan seseorang terhadap tuhannya saja secara syar'i, akan tetapi dalam hal ini di masyarakat Sasak haji mempunyai pengaruh-pengaruh dan makna-makna tersendiri yang dalam praktiknya terjadi semacam akulturasi nilai agama dan budaya lokal Sasak. Oleh sebab itu haji akan mempengaruhi banyak hal dalam dimensi sosial dan perubahan dalam masyarakat, sebut saja orang yang berhaji dalam masyarkat akan mempengaruhi status seseorang yang sebelumnya merupakan masyarkat biasa kemudian sepulangnya dari haji ia akan mempunyai status yang berbeda dan perlakuan yang berbeda pula dalam masyarakatnya. Di dalam masyarakat Sasak sendiri labelisasi seseorang sebagai haji 
merupakan halyang sangat istimewa bagi mereka karena perlakuan masyarakat umum terhadap para penyandang setatus haji berbeda dengan masyarakat biasa, sehingga tidak heran apabila kita melihat fenomena haji dalam masyarakat Sasak di mana antusias masyarakatnya sangat tinggi untuk melaksanakan ibadah haji (Sya'rani, 2017, hal. 13)

Hal ini menunjukkan bahwa mengkaji fenomena maraknya ibadah haji serta menyelaminya secara lebih kompleks memang sudah makin tidak cukup jika tidak menggunakan instrumen gaya hidup kelas menengah sebagai penjelasan. Sebab tidak bisa dihindari lagi kalau haji dan umrah lebih mirip instrumen gaya hidup kelas menengah daripada ritus ibadah semata. Hal seperti ini memang telah banyak diamati oleh para peneliti keagamaan. Azyumardi Azra (2010, hal. 365) misalnya mengemukakan “...naik haji bahkan juga umrah yang sekarang semakin marak dan fashionable pada masa-masa super jet jumbo sekarang ini cenderung menjadi mode dan fashion, bagian dari gaya hidup kontemporer". Pada akhirnya, fenomena tentang tingginya animo berhaji harus lebih banyak menggunakan perspektif teoritik lain seperti perspektif ekonomi, politik, psikologi, dan sosiologi perubahan sosial ketimpang meneliti dan mengkaji ibadah haji sebagai ritual ibadah semata (Tahir, 2016).

\section{Simpulan}

Kondisi masyarakat Kudus yang mayoritas beragama Islam dan berprofesi sebagai pedagang dengan pendapatan ekonomi yang baik sangat memungkinkan bagi mereka memiliki antusias tinggi untuk melaksanakan haji, bahkan mengadakan pengulangan haji untuk yang kedua dan seterusnya. Sejak dahulu kabupaten Kudus selalu menempati peringkat lima besar peserta jamaah haji terbanyak di propinsi Jawa Tengah.

Motif masyarakat muslim Kudus mengulangi hajinya tidak semata-mata berupa motif religius, yakni untuk mencari ridla Allah saja, tetapi juga motif psikologi. Motif psikologi terkait dengan kebutuhan-kebutuhan psikis, seperti mendapat penghargaan, mencintai dan dicintai pasangan, aktualisasi diri sebagai wujud kemampuan diri (istitha'ah). Dari sudut pandang teori harapan (expectancy theory), masyarakat Kudus percaya bahwa dapat mengulang haji merupakan fadhal Allah sebagai wadah mereka untuk mewujudkan segala harapan duniawi maupun ukhrawi. Dampak nyata dari 
ibadah haji, baik di saat sedang proses berhaji maupun sesudahnya, mampu menjadi daya tarik tersendiri bagi masyarakat Kudus untuk mengulang ibadah hajinya. Meski masyarakat Kudus sadar bahwa berhaji memerlukan biaya besar, tenaga dan upaya yang optimal, namun hal tersebut menjadi tidak berarti dibandingkan dengan hasil dan dampak berhaji yang luar biasa dalam kehidupan mereka. Motif mengulangi haji juga karena keyakinan bahwa biaya haji akan diganti dan dilipatgandakan oleh Allah melalui peningkatan kuantitas dan kualitas ekonomi sepulang dari melaksanakan ibadah haji.

Artikel ini masih bersifat lokal yang kesimpulannya belum bisa digeneralisir, maka sangat memungkinkan untuk dilakukan penelitian sejenis di lokasi lain dalam skala lebih luas, baik nasional, regional maupun internasional untuk dapat memotret fenomena motif pengulangan haji secara utuh dan komprehensif. Kendala yang penulis alami dalam menentukan informan yang pernah mengulangi hajinya, memungkinkan juga akan menjadi kendala bagi kajian serupa dalam skala yang lebih besar. Hal ini disebabkan memang data ataupun informasi pihak-pihak yang pernah mengulangi hajinya tidak dapat ditemukan secara administratif, terutama di Kasi haji dan umrah kementerian agama.

\section{Terima kasih}

Artikel ini merupakan hasil penelitian yang didanai oleh Bantuan Operasional Perguruan Tinggi Negeri (BOPTN) Institut Agama Islam Negeri Kudus 2018. 


\section{Referensi}

Alex Shobur. (2003). Psikologi Umum. Bandung: CV Pustaka Setia.

Andjarwati, T. (2015). Motivasi dari Sudut Pandang Teori Hirarki Kebutuhan Maslow, Teori Dua Faktor Herzberg, Teori xy Mc Gregor, dan Teori Motivasi Prestasi Mc Clelland. Jurnal Ilmu Ekonomi \& Manajemen, 1(1), 45-54.

Azra, A. (2010). Ibadah Haji dan Rihlah Makkiyah: Dampaknya dalam Dinamika Islam Indonesia dalam Dinamika dan Perspektif Haji Indonesia. Jakarta: Dirjen Haji dan Umrah Kementerian Agama.

C. Moustakas. (1994). Phenomenological Research Metdhos. Thousand Oaks California: Sage Publications.

Farhan, N. (2017). Problematika Waiting List Dalam Penyelenggaraan Ibadah Haji Di Indonesia. Jurnal Studi Agama dan Masyarakat, 12(1), 57-80.

Fatkhi, R. M. (2018). Haji Berulang Telaah Hadis Haji Lebih Dari Sekali.

Firdaus, M. (2017). Haji Madura (Kajian Konstruksi Sosial Budaya Mengenai Haji Pada Masyarakat Madura Di Kelurahan Sidotopo, Kecamatan Semampir, Kota Surabaya.

Ichwan, M. N. (2008). Governing Hajj: Politics of Islamic Pilgrimage Services in Indonesia Prior to Reformasi Era. Aljamiah: Journal of Islamic Studies, 46(1), 126151.

Indrahti, S., Alamsyah, A., \& Maziyah, S. (2013). Dinamika Islamisasi di Kudus: Menggali Nilai-nilai Ketokohan Para Sunan pada Wisata Ziarah di Kudus. HUMANIKA, 18(2).

Istianah, I. (2017). Hakikat Haji Menurut Para Sufi. Esoterik: Jurnal Akhlak dan Tasawuf, 2(1).

J.W. Creswell. (1998). Qualitative Inquiry and Research Design: Choosing Among Five Traditions. Thousand Oaks California: Sage Publications.

Jalaluddin. (2015). Psikologi Agama: Memahami Perilaku dengan Mengaplikasikan Prinsip-prinsip Psikologi. Jakarta: PT Raja Grafindo Persada.

Lestari, L. (2014). Tafsir Ayat-Ayat Perintah Haji Dalam Konteks Ke-Indonesiaan. ESENSIA: Jurnal Ilmu-Ilmu Ushuluddin, 15(1).

Mawardi. (2016). Batasan dan Aspek-aspek Agama dalam Perspektif Sosiologi. Substantia, 18(2), 219-232.

Nisa, K. (2017). Haji dan kesadaran humanisme: makna sosial khutbah haji 
wada'(kajian hadits tematik) (thesis). UIN Syarif Hidayatullah Jakarta: Fakultas Ushuluddin, 2017.

Perdana, L. R. (2017). Tema-tema Pengalaman Beragama pada Individu yang Melaksanakan Ibadah Haji. Jurnal Psikologi Islam, 4(1), 71-76.

Priyadi, E. (2017). Kajian Teori Maslow terhadap Motivasi Menjadi Guru Sekolah Minggu di Gereja Kristen Jawa Tangerang.

Rapiko, R. (2011). Haji, Turisme, dan Pencarian Kesalehan. Kontekstualita: Jurnal Penelitian Sosial, 26(1).

Said, N. (2010). Jejak Perjuangan Sunan Kudus. Yogyakarta: Brillian Media Utama. Shobur, A. (2003). Psikologi Umum. Bandung: CV Pustaka Setia.

Sujadi, A. (2017). Kriminalisasi Pengulangan Haji Di Indonesia. IN RIGHT: Jurnal Agama dan Hak Azazi Manusia, 2(2).

Sulthoni, M., \& Muhlisin, M. (2013). Haji Dan Kegairahan Ekonomi: Menguak Makna Ibadah Haji Bagi Pedagang Muslim di Yogyakarta. JURNAL PENELITIAN, 9(1).

Suryana, Y. (2013). Tradisi Pamitan Haji pada Masyarakat Muslim Purwomartani Kalasan Yogyakarta: Kontestasi Agama dan Budaya. Sosiologi Reflektif, 8(1).

Sya'rani, M. (2017). Haji Dalam Lokalitas Masyarakat Sasak. Tarbawi: Pendidikan Islam dan Isu-isu Sosial, 4(4).

Syarifah, U. (2009). Motif Sosial Melakukan Ibadah Haji pada Masyarakat Desa Umbulmartani di Kecamatan Ngemplak. Universitas Islam Negeri Sunan Kalijaga Yogyakarta.

Tahir, H. (2016). Haji dan Umrah sebagai Gaya Hidup: Pertumbuhan Bisnis Perjalanan sSuci di Kota Makassar. Al-Qalam, 22(2), 127-139.

Toguslu, E. (2017). The Meaning of Pilgrimage (Hajj): Re-shaping the Pious Identity of Belgian Turkish Muslims. Islam and Christian-Muslim Relations, 28(1), 19-32. https://doi.org/10.1080/09596410.2017.1282721

Zainuddin, M. (2013). Haji Dan Status Sosial: Studi Tentang Simbol Agama Di Kalangan Masyarakat Muslim. El-HARAKAH, 15(2), 169-184.

Zakiah Daradjat. (1970). Ilmu Jiwa Agama. Jakarta: Bulan Bintang. 
Halaman ini bukan sengaja untuk dikosongkan 